\title{
The Effect of Flaxseed Oil (Linum usitatissimum) on Lipid Metabolism of Cholesterol Fed Rats
}

\author{
Suaad M. J. Al-Hadrawy, Ikhlass A. Al-Hilaly and Haider A. Thanwan Al-Kafajy \\ College of Science, University of Kufa.
}

\begin{abstract}
This research designed to study the effects of flaxseed oil $(0.25 \mathrm{ml})$ orally given for 28 days on the total cholesterol concentration and on lipid lipoprotein in the blood of cholesterol fed rats. Methods: Randomly 12 adult female rats were divided into 4 groups ( 3 animals for each group). The control group ( group I) were fed with standard pellet diet, the second group (group II) were fed with $1 \%$ cholesterol diet, the third group (group III) were daily administered $(0.25 \mathrm{ml})$ of the flaxseed oil along with high cholesterol diet, and the fourth group (group IV) received daily (0.25 $\mathrm{ml}$ ) of flaxseed oil. Results: The results showed a disturbance state in blood lipids in the animals that fed with diet contain cholesterol characterized with significant increase in total cholesterol (TC) and the concentration of low density lipoprotein (LDL-C) and triglyceride (TG) and in the very low density lipoprotein (VLDL-C) in the serum and a significant decrease in the level of high density lipoprotein (HDL-C) concentration. Also the result showed that flaxseed oil administration has no protective effects against this lipid disturbance which induced by cholesterol use. Conclusion: The treatment with flaxseed oil didn't cause significant decrease in total cholesterol level and didn't cause increase the level of High density lipoprotein in the plasma of treated rats.
\end{abstract}

Keywords: flaxseed oil; cholesterol; triglycerides; HDL-C; LDL-C.

\section{Introduction}

The use of flaxseed as a dietary supplement is increasing in parallel with the research on its multitudinous effects on human health (1). Flaxseed contains putative health promoting factors like nutritional fiber, the phytoestrogen lignan precursors secoisolariciresinol and matairecinol and flaxseed oil with its high concentration of $\alpha$ linolenic acid (2).

Flaxseeds contain 35-45 \% oil. Flaxseed oil has an exceptional fatty acid composition: depending on the strain $45-60 \%$ of it is alphalinolenic acid (ALA) and 15-18\% is linoleic acid (LA). ALA and LA fatty acids are essential i.e. they must be included in the diet (1).

ALA shows cancer-preventive effects $(3,4)$, an inverse association with risk of coronary heart disease (5) and beneficial effects on hemostatic factors (6). ALA is involved also in inflammatory diseases by decreasing leukotriene $\beta_{4}$ concentration (7) and in atopic disease (8). ALA seems to have a beneficial role also on brain function (9).

In laboratory and animal studies, flaxseed and flaxseed oil are reported to lower blood cholesterol levels. Effects on blood triglyceride levels in animals are unclear, with increased levels in some research and decreased levels in other research. Human studies in this area report mixed results, with decreased blood levels of total cholesterol and low-density lipoprotein (bad cholesterol) in some studies, but no effect in other studies $(10,11,12)$.

Atherosclerosis is the leading cause of cardiovascular morbidity and mortality (13). Atherosclerosis induces two significant pathological processes: an ischemic event due to blood flow obstruction and vascular contractile dysfunction. It is well known that atherosclerosis is associated with elevated circulating cholesterol levels $(14,15)$.

Therefore, this study was designed to investigate the effect of the flaxseed oil on lipid profile system in cholesterol fed rats.

\section{Materials and Methods}

Numbers of mature female rats were housed under standard condition and freely access to water and standard diet along the experiment except when indicated, high cholesterol diet were prepared daily by addition of $1 \%$ cholesterol to the standard diet (16). Flaxseed oil were obtained from Mehta 
Oil Mills (India).

Twelve adult female albino rats (220$250 \mathrm{gm})$ were randomly divided into four groups (each of 3 animals). group I (control) received standard pellet diet, group II received high cholesterol diet, group III were administered $(0.25 \mathrm{ml})$ of the flaxseed oil along with high cholesterol diet, and; group IV received $(0.25 \mathrm{ml})$ of flaxseed oil, at the end of experiment, fasting blood samples was drawn at 28 days of treatments by cardiac puncture technique, where plasma was immediately separated and stored at $-20 \mathrm{C}^{\mathrm{o}}$ until assayed of TC, TGs, HDL-C and VLDL-C concentrations using a standard enzymatic assay (Biomeriux Vitek. Inc. USA, Linear chemicals kit, Spain, respectively). Serum LDL-C was calculated by subtracting the sum of HDL-C and VLDL-C from total cholesterol (17).

Data are expressed as means \pm SE. Statistical comparisons were made using oneway ANOVA, followed by least significant difference test. Defferences between means were considered significant when $\mathrm{p}<0.05$.

\section{The Results}

\section{Effect of flaxseed oil on plasma TC and TGs of cholesterol fed rats}

Table (1) showed a significant increase $(195.6 \pm 4.05, \quad 191.6 \pm 4.40) \quad(p<0.05) \quad$ in the total cholesterol concentration in the serum of group II and III in comparison with the control group, $(68 \pm 1.527)$ while in group IV the total cholesterol concentration decreased insignificantly $(59.3 \pm 2.333)$ ( $>0.05)$ in comparison with the control which was $(59.3 \mathrm{mg} / \mathrm{dl})$.

The results also showed in Table (1) a significant increase in TGs concentration $(85.33 \pm 3.179,80 \pm 2.516)$ in II and III groups when compared with the control group (49.33 \pm 5.06$)$, while in IV group TGs concentration decrease significantly $(25.33 \pm 6.741)(\mathrm{p}<0.05)$ in comparison with the control.

\section{Effect of flaxseed oil on plasma lipid profile of cholesterol fed rats}

Table (2) showed a significant decrease $(43.666 \pm 4.484, \quad 50.66 \pm 1.201)(\mathrm{p}<0.05) \quad$ in HDL-C concentration in group II and III in comparison with the control group $(62.833 \pm 1.666)$ and IV group $(60 \pm 2.516)$, while in group IV there was no significant changes $(p>0.05)$ in HDL-C in comparison with the control group.

The results showed in Table (2) a significant increase (18.1 $0.665,17.3 \pm 0.405)$ $(\mathrm{p}<0.05)$ in VLDL-C and LDL-C $(133.9 \pm 7.15$, $123 \pm 5.9)$ in group II and group III when compared with the control group (7.63 \pm 2.543$)$, also the results showed Table (1) a significant decrease $(5.06 \pm 1.348)(\mathrm{p}<0.05)$ in VLDL in IV group in comparison with the control (12.8 \pm 0.953$)$, but the LDL-C in IV group didn't show any significant difference $(5.73 \pm 0.94) \quad(p>0.05)$ from the control $(7.63 \pm 2.543)$. 
Table (1)

Total serum cholesterol and triglycerides $(\mathrm{mg} / \mathrm{dl})$ in cholesterol fed rats treated with flaxseed oil for 28 Days.

\begin{tabular}{|c|c|c|c|c|c|}
\hline \multicolumn{2}{|l|}{ Groups } & \multicolumn{2}{|c|}{ Total cholesterol } & \multicolumn{2}{|c|}{ Triglycerides } \\
\hline Control & (group I) & $68 \pm 1.527$ & & $49.33 \pm 5.206$ & \\
\hline Cholesterol fed & (group II) & $195.6 \pm 4.05$ & $\mathbf{a}$ & $85.33 \pm 3.179$ & $\mathbf{a}$ \\
\hline Cholesterol + flaxseed oil & (group III) & $191.6 \pm 4.40$ & $\mathbf{a}$ & $80 \pm 2.516$ & $\mathbf{a}$ \\
\hline Flaxseed oil & (group IV) & $59.3 \pm 2.333$ & & $25.33 \pm 6.741$ & $\overline{\mathbf{a b}}$ \\
\hline LSD & & 10.775 & & 15.38 & \\
\hline
\end{tabular}

Values are expressed as mean \pm S.E., $n .=3 /$ group . a significant difference $(p<0.05)$ from control group. $b$ significant difference $(p<0.05)$ from other groups.

Table (2)

Serum (HDL-C, LDL-C and VLDL-C) concentration (mg/dl) in cholesterol fed rats treated with flaxseed oil for 28 Days.

\begin{tabular}{|c|c|c|c|}
\hline Groups & $H D L-C$ & $L D L-C$ & $V L D L-C$ \\
\hline (group I) & $62.833 \pm 1.166$ & $7.63 \pm 2.543$ & $12.8 \pm 0.953$ \\
\hline Cholesterol fed & $433.666 \pm 4.484 \mathbf{a}$ & $133.9 \pm 7.15 \mathbf{a}$ & $18.1 \pm 0.665$ \\
\hline Cholesterol +flaxseed oil (group III) & $50.66 \pm 1.201 \quad \mathbf{a}$ & 123. $\pm 5.6 \quad \mathbf{a}$ & $17.3 \pm 0.405 \quad \mathbf{a}$ \\
\hline $\begin{array}{ll}\text { Flaxseed oil } & \text { (group IV) }\end{array}$ & $60 \pm 2.516$ & $5.73 \pm 0.94$ & $5.06 \pm 1.348 \mathrm{ab}$ \\
\hline$\overline{\mathrm{LSD}}$ & 8.818 & 15.465 & 2.978 \\
\hline
\end{tabular}

Values are expressed as mean \pm S.E., $n .=3 /$ group.

(a) significant difference $(p<0.05)$ from control group.

(b) significant difference $(p<0.05)$ from other groups.

\section{Discussion}

This study showed that a high-cholesterol diet produced an increase in serum TC, TGs, LDL-C and VLDL-C and decrease in serum HDL-C concentration. Cholesterol in consider as a major contributing factor responsible for the modification of the rate of the hepatic lipoprotein synthesis leading to an increase in plasma VLDL-C and LDL-C concentration in normal and hypercholesterolemic subjects. $(18,19)$. Furthermore, it has been shown that changes (increased in LDL-C and VLDL-C) may be at least in part, due to changes in the hepatic expression of genes such as lipoprotein receptors, apolipoprotein $\beta$ and the microsomal TG transfer protein (20).

The increase in serum TGs level in animals received high cholesterol diet may be due to an increase in serum VLDL-C level which act carrier for the TGs in the serum (21). Serum HDL-C level have been reported to be inversely correlated with serum VLDL-TGs levels both in normolipidemic and hyperlipidemic subjects (22).

The decrease in serum HDL-C was observed in the current study is associated with increase in serum VLDL-C and TGs levels in cholesterol fed rats (Table 1 and 2). Intervention of the flaxseed oil along with cholesterol didn't reduce the levels of serum TC, TGs, LDL-C and VLDL-C and didn't increase the levels of serum HDL-C concentration.

Flaxseed oil is rich in an essential fatty acid called alph-linolenic acid (ALA), used as a source of energy by the body. It also serves as the parent substance to compounds that regulate blood pressure, blood clotting, heart rate, blood vessel dilation, the immune response, and the breakdown of fats (6).

Flaxseed contain $35 \%$ of its mass as oil, of which $55 \%$ is ALA (w-3 fatty acid) and $15 \%$ to $18 \%$ is LA $(23,24)$. It is a rich source of w-3 fatty acid and the richest source of plant 
lignans (25). Flaxseed has been shown to be effective in reducing hypercholesterolemic atherosclerosis by $46 \%$ without lowering serum cholesterol (12). Crop Development Center (CDC)-flaxseed, which has an oil content (35\% of total mass) and concentration of Lignan secoisolariciresinol diglucoside (SDG) $(16.4 \mathrm{mg} / \mathrm{g}$ versus $15.4 \mathrm{mg} / \mathrm{g}$ defatted meal) similar to those of ordinary flaxseed but has only $2 \%$ to $3 \%$ of $\alpha$-linolenic acid content, reduced the development of hypercholesterolemic atherosclerosis by $69 \%$ and reduced serum cholesterol and LDL-C $\approx 31 \%$ to $32 \%$ (26). These results suggest that the hypocholesterolemic activity of flaxseed is not due to ALA but may be to the lignan component of the meal. (27).

In conclusion, flaxseed oil has not shown any hypolipidemic effect.

\section{References}

[1] Tarpila A, Wennberg T, Tarpila S. Flaxseed as a functional food. Current Topics in Nutraceutical Research; 3 (3): 167-188, 2005.

[2] Tarpila S, Aro A, Salminen I, Tarpila A, Kleemola P, Akkila J, Adlercrentz. The effect of flaxseed supplementation in processed foods on serum fatty acids and enterolactore. European Journal of clinical nutrition.; 56:157-165, 2002.

[3] Klein V, Chajes V, Germain E, Chilgen G, Pinault M, Malvy D, Lefrancq T, Fignon A, Le Floch O, Lhuillery C, and Bougnoux P. Low alpf-linolenic acid content of adipose breast tissue is associated with an increased risk of breast cancer? Eur. J. Cancer.; 36:335-340, 2000.

[4] Cognault S, Jourdan ML, Germain E, Pitavy R, Morel E, Durand G, Bougnoux P and Lhuillery $\mathrm{C}$. Effect of an $\alpha$-linolenic acid-rich diet on rat mammary tumor growth depends on the dietary oxidative status. Nutr.Cancer; 36: 33-41, 2000.

[5] Ascherio A, Rimm EM, Giovannucci EL, Spiegelman D, Stampfer M and Willet WC. Dirtary fat and risk in coronary heart disease in men: cohor follow up study in the united states. Br.Med. J. 313(7049):84-90, 1996.

[6] Allman-Farinelli MA, Hall D, Kingham K, Pang D, Petocz P, Favaloro EJ. Comparison of the effects of two low fat diets with different $\alpha$-Linolenic acid ratios on coagulation and fibrinolysis. Atherosclerosis.; 142:159-168, 1999.

[7] Geerling BJ, v Houwelingen AC, BadartSmook A, Stockbrugger RW and Brummer RJ. Fat intake and fatty acid profile in plasma phospholipids and adipose tissue in patients with Crohn's disease, compared with controls. Am. J. Gastroenterol. 94: 410-417, 1999.

[8] Kankaanpää P, Sutas Y, Salminen S, Lichtenstein A, and Isolauri E. Dietary fatty acids and allergy. Ann. Med. 31:282-287, 1999.

[9] Youdim KA, Martin A, Joseph JA. Essential fatty acids and the brain: possible health implications. Int.J. Dev. Neurosci. 18:383-399, 2000.

[10] Arjmandi BH, Khan DA, Juma S, et al. Whole flaxseed consumption lower serum LDL-cholesterol and lipoprotein (a) concentration in postmenopausal women. Nutrit Res; 18 (7): 1203-1214, 1998.

[11] Hu FB, Stampfer MJ, Manson JE, et al. Dietary intake of alpha-linolenic acid and risk of fatal ischemic heart disease among women. Am J Clin Nutr; 69(5):890-897, 1999.

[12] Prasad K. Dietary flaxseed in the prevention of hypercholesterolemic atherosclerosis by CDC-flaxseed with very low alpha-linolenic acid. Atherosclerosis. 132: 69-76, 1997.

[13] Yusuf S, Hawken S, Ounpuu S, Dans T, Avezum A, Lanas F, McQueen M, Budaj A, Pais P, Varigos J, and Lisheng L. Effect of potentially modifiable risk factors associated with myocardial infarction in 52 countries (the INTERHEART study): casecontrol study. Lancet, 364:937-952, 2004.

[14] Bossaller C, Yamamoto H, Lichtlen PR, and Henry PD.Impaired cholinergic vasodilation in the cholesterol-fed rabbit in vivo. Basic Res Cardiol 82: 396-404, 1987.

[15] Hayashi T, Yamada K, Esaki T, Kano H, Asia Y, Kumar Thakur N, Jayachandran M, Sumi D, and Iguchi A. Endotheliumdependent relaxation of rabbit atherosclerotic aorta was not restored by control of hyperlipidemia: the possible role of peroxynitrite (ONOO(-)). Atherosclerosis; 147:349-363, 1999. 
[16] Haulbron G, Aubert R, Bourgeios F, Lemonnier D. Early cholesterol feeding: are there long-term effects in the rats?. $J$ Nutr. 112 (7):1296-1304, 1982.

[17] Friedwald WT, Levy RRI, Fredrickson DS, Estimation of concentration of lowdensity lipoprotein cholesterol in plasma without the use of preparative ultracentrifuge. Clin Chem. 18:499-502, 1972.

[18] Mangiapane E H, McAteer M A, Benson G M, White D A, Slater M A, Modulation of the regression of atherosclerosis in the hamster by dietary lipids: Comparison of coconut oil and olive oil. British J. Nutr. 82:401-409, 1999.

[19] Hder K Stang G. Plasma thyroxin and cholesterol concentration of miniature pigs are influenced by thermally oxidized dietary lipids. $J$ Nutr, 130(1):116-121, 2000.

[20] Salter A M, Mangiapane E H, Bennett A J, Bruce J S, Bilett M A, Anderton K L, Marenah C B, Lawson N and White D A. The effect of different dietary fatty acids on lipoprotein metabolism: Concentrationdependent effects of diets enriched in oleic, myristic, palmitic and stearic acids. British J. Nutr. 79:195-202, 1998.

[21] Criqui $\mathrm{M} H$ and Golomb B A. Epidermiologic aspects of lipid abnormalities. Am J. Med. 105 (1A):48S57S, 1998.

[22] Gaziano J M, Hennekens C H, O'Donnel C J. Fasting triglycerides], high density lipoprotein, and risk of myocardial infraction. Circulation 96: 2520-2525, 1997.

[23] Carter J. Flax seed as a source of alpha linolenic acid. J. Am. Coll Nutr. 12:551, 1993.

[24] Cunnane SC, Ganguli S, Menard C, Liede AC, Hamadeh MJ, Chen Z-Y, Wolever TMS, Jenkins DJA. High alphlinolenic acid flaxseed (Linum usitatissimum): some nutritional properties in humans. Br. J. Nutr. 69:443-453, 1993.

[25] Hunter JE.n-3 fatty acids from vegetable oils. Am. J. Clin. Nutr. 51: 809- 814, 1990.

[26] Prasad K. Mantha SV, Muir AD, Westcott ND. Reduction of hypercholesterolemic atherosclerosis.
Atherosclerosis. 136(2):367-375, 1998.

[27] Prasad K. Reduction of serum cholesterol and hypercholesterolemic atherosclerosis in rabbits by secoisolariciresinol diglucoside isolated from flaxseed. Circulation. 99:1355-1362, 1999.

الخلاصة

هدف البحث: صمم هذا البحث لدراسة تأثير زيت بذور الكتان

(0.25)مل عن طريق الفم لمدة 28 يوماعلى تركيز

الكولستيرول الكلي وعلى حالة الدهون والثحوم البروتينية للام

$$
\text { في الجرذان المغذاة على الكولستيرول. }
$$

طريقة البحث: تم عشوائيا تقسيم اناث الجرذان البالغة الى لى لى

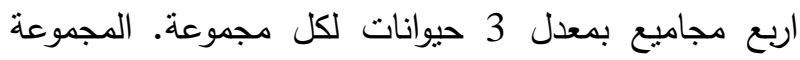

الاولى (سيطرة) اعطيت العلف العادي، تم تغذية حيوانات

المجموعة الثانية بعليقة حاوية على 1\% كولستيرول في حين

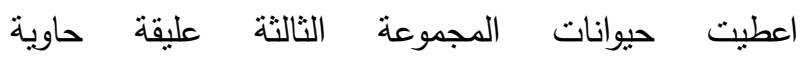

على 1\% كولستيرول وجرعت يوميا بزيت بذور الكتان

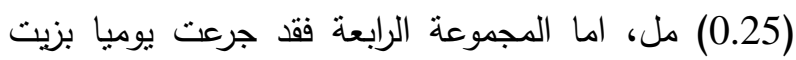

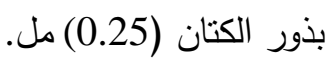

النتائج: أشنارت النتائج الى حدوث حالة اضطراب دهن دهون الدم

في الجرذان المغذاة على عليقة حاوية على الكولستيرول تميزت بزيادة معنوية في تراكيز كل من الكولستيرول الكلي

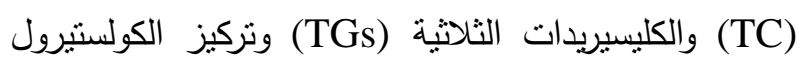
في الثحوم البروتينية ذات الكثافة الواطئة جدا (VLDL-C)

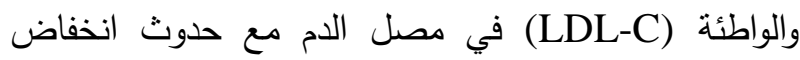
معنوي في مستوى الكولسترول في الثحوم البروتينية ذات

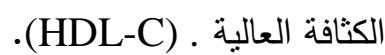

الاستتتاج: أظهرت نتائج هذه الدراسة بأن اعطاء زيت بذور الكتان ليس له تأثثرات وقائية ضد حالة اضطراب الدهون لهاه المحدثة بسبب استخدام الكولستيرول .حيث لم تؤدي المعاملة

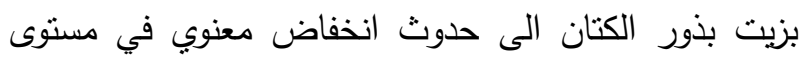
الكولستيرول الكلي ولم تسبب ارتفاع تركيز الثحوم البروتينية ذات الكثافة العالية في بلازما دم الجرذان المعاملة. 